H. G. WELLS: DISCOVERER OF THE FUTURE 


\section{H. G. WELLS: DISCOVERER OF THE FUTURE}

THE INFLUENCE OF SCIENCE ON HIS THOUGHT

Roslynn D. Haynes

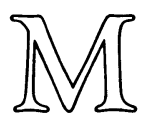


(C) R. D. Haynes 1980 Softcover reprint of the hardcover 1st edition 1980 978-0-333-27186-5

All rights reserved. No part of this publication may be reproduced or transmited, in any form or by any means, without permission

First published 198o by THE MACMILLAN PRESS LTD London and Basingstoke Associated companies in Delhi Dublin Hong Kong Johannesburg Lagos Melbourne New York Singapore Tokyo

British Library Cataloguing in Publication Data

Haynes, R. D.

H. G. Wells, discoverer of the future

I. Wells, Herbert George - Knowledge - Science

I. Title

$823^{\prime} \cdot 9^{\prime}$ I2 $\quad \mathrm{PR}_{5778 . S /}$

ISBN 978-1-349-04870-0 ISBN 978-1-349-04868-7 (eBook) DOI 10.1007/978-1-349-04868-7

This book is sold subject to the standard conditions of the Net Book Agreement 
For Raymond, Nicola and Rowena and for my parents 


\section{Contents}

Preface ix

Acknowledgments $\quad$ xi

Introduction I

Part I Wells's Scientific Background. Scientist or Visionary? 9

I The Conversion to Science

2 Scientific Method and Wells's Credentials 39

Part II Science in Society 67

3 Science and Technology 69

4 Science and Government - the Wellsian Utopia 82

5 Waste and Disorder or Order and Uniformity? I 2

6 Free Will and Predestination: Freedom and Limitation $\quad$ I27

7 Science as Myth and Mysticism 143

Part III Science and the Approach to Characterisation I6I

8 Wells's Concept of the Individual $\quad 163$

9 The Scientist as a Literary Character 197

Part IV Wells's Techniques and his Approach to Art 219 10 Techniques of Persuasion and Presentation $22 \mathrm{I}$

I I Art, Science and Structure: the Debate with Henry James 24I

Notes 253

Bibliography $\quad 268$

Index 281 


\section{Preface}

As a scientist who defected to the literary camp I have long been struck by the profound effect that scientific developments had on the literature of the nineteenth century, and the lamentable lack of such cross-fertilisation in the twentieth.

H. G. Wells was the last great literary figure to have been so strongly influenced by science. Not only did contemporary theories contribute ideas to his books, but he, in turn, predicted so many consequences of current scientific knowledge that he had the misfortune to be hailed as a prophet. His scientific romances, short stories, novels, blueprints for utopia, his history of the world and encyclopaedic textbooks of biology, sociology and economics, made him the most widely read author in the language, and secured him the respect of even Roosevelt and Stalin.

But if a prophet can be said to be without honour in his own country, he is even more bereft of it in the next generation, and Wells is no exception. The reprisals taken by the generation following him have been severe. In their zeal to show how gullible their fathers were, critics have reduced Wells's scientific romances to the status of imaginative fairy tales which merely pretend to authenticity by a scattering of scientific terms. The utopian and sociological novels have fared still worse. They do not win even the minor award for imaginative merit, but are rejected on grounds of both form and content.

Whatever the immediate outcome of the controversy between Wells and Henry James about the novel form, James succeeded in the long term in converting the more influential critics to his own artistic criteria, which could not accommodate Wells's writings. In addition, since the I930s, utopias have become universally suspect, for it is assumed that they are all merely cowardly fronts for a brave new world, or a 1984 concentration camp.

It is the purpose of this book to trace the actual extent of the scientific influence on Wells's thought, not only as it appears in the scientific romances, but in the character novels and utopian works as well. 
As a result of this influence, Wells was a prophet, not merely in the popular sense of having predicted space travel, processed food and the Common Market, but in the wider sense of being able to think in a completely new way about the future - to be, as it were, at home in the future. Such a way of thinking freed him, as he immediately realised, from much of the seemingly iron-bound determinism under which nineteenth-century novelists had laboured; it provided a new perspective from which to view man in his personal and social relationships.

Any balanced assessment of Wells's contribution to literature must take account of his sins against the canons of form, but it should not neglect his enthusiastic attempts to break the mind-forged manacles of the present. 


\section{Acknowledgments}

It is a great pleasure to be able to thank Dr Peter Keating of the University of Edinburgh for the stimulating discussion and helpful comments which accompanied the preliminary stages of this book.

Throughout all stages of its gestation I have been blessed with the encouragement and enthusiastic support of my parents and two daughters, and especially of my husband, who has in addition contributed everything from exhaustive discussions on relativity to exhausting bouts of household management.

The author and publishers wish to thank the Executors of the Estate of H. G. Wells and Professor G. P. Wells for permission to quote from the works of H. G. Wells. 